\title{
Effects of Fuel Reduction Treatments on Avian Nest Density in the Upper Piedmont of South Carolina
}

\author{
Eran S. Kilpatrick ${ }^{*}, 1$ Joseph D. Lanham ${ }^{2}$, and Thomas A. Waldrop ${ }^{3}$ \\ ${ }^{1}$ Division of Math and Science, University of South Carolina Salkehatchie, PO Box 1337, Walterboro, SC 29488, USA \\ ${ }^{2}$ Department of Forestry and Natural Resources, Clemson University, 261 Lehotsky Hall, Clemson, SC 29634, USA \\ ${ }^{3}$ U.S. Forest Service, 239 Lehotsky Hall, Clemson, SC 29634, USA
}

\begin{abstract}
The Fire and Fire Surrogate Study is a national study installed at 13 sites across the United States. One goal of the southeastern Piedmont FFS installation was to assess the effects of fuel reduction treatments such as prescribed burning and thinning on avian nest density. Nest searching and monitoring took place within twelve 10-hectare study plots during the breeding seasons of 2003 and 2004. A total of 82 nests representing 23 species were discovered and monitored. Seventy-two percent of those nests were successful in fledging young and $28 \%$ failed. Higher quantities of herbaceous material, shrubs, and small diameter trees provided more nesting substrate in Thin/Burn and Burn plots. This study suggests that prescribed burning and a combination of prescribed burning and thinning may be beneficial for Southern Piedmont bird communities, but our conclusions must be considered in light of the small sample sizes of nests. Increasing the area of upland Piedmont forest receiving prescribed burning and thinning treatments could possibly benefit early successional species that are presently experiencing population declines across the United States.
\end{abstract}

Keywords: Avian nesting success, fire and fire-surrogate study, fuel reduction treatments, piedmont of South Carolina.

\section{INTRODUCTION}

The National Fire and Fire Surrogate Study (FFS) was initiated in the Clemson Experimental Forest in spring 2000 to study the ecological and economical consequences of four fuel reduction treatments over a 5-year period. The Clemson Experimental Forest, which served as the southeastern Piedmont FFS site, is located in the upper Piedmont of Northwestern South Carolina, USA. The Piedmont region covers nearly $34 \%$ of South Carolina. In the past, $95 \%$ of the land in the Piedmont was in agriculture. At present, a majority of the Piedmont is forested and composed of mixed hardwood pine forests and loblolly pine (Pinus taeda Linnaeus) plantations. Although forests make up a large portion of this subregion, significant areas are still in agriculture [1].

Research assessing the effects of fire and thinning on bird abundance in the South are well documented [2-5]. The listing of the Red-cockaded Woodpecker (Picoides borealis Vieillot) on the endangered species list and interest in Neotropical migrant conservation have resulted in a large body of knowledge concerning the effects prescribed fire and thinning on avifauna. Wade and Johansen [6] have shown that fire in southern pine forests removes vegetation and fuels, opens the forest canopy, and keeps hardwood growth in check. Successional changes in vegetation over time may change patterns of avian habitat use. After disturbance, early successional bird species are often detected but as

*Address correspondence to this author at the Division of Math and Science, University of South Carolina Salkehatchie, PO Box 1337, Walterboro, SC 29488, USA; Tel: 843-549-6314; Fax: 843-549-6007;

E-mail: ERANKIL@mailbox.sc.edu mid-canopy and canopy trees mature, the number of forest interior species increase [7]. Avian species that respond to prescribed fire and thinning span an ecological continuum from habitat generalists such as Carolina chickadees (Poecile carolinensis Audubon) to habitat specialists such as Bachman's sparrow (Aimophila aestivalis Audubon).

Nest density and success is an additional parameter used to evaluate the effects of fuel reduction treatments on avifauna. Nest predation is reported to be greater in edge habitat than in forest interior habitat [8] and nest parasitism by brown-headed cowbird (Molothrus ater Boddaert) has been related to declines in some Neotropical migrants $[9,10]$. Nest predation has also been found to be positively related to the number of shrub-nesting species [11]. Nest survival has been found to be lower in thinned [12] and burned stands [13], but higher in unharvested forest [14]. Zebehazy [15] reported minimal differences in avian abundance between treatment and control plots in the southeastern Piedmont FFS site from 2001-2002. After two breeding seasons, 79 nests were found and monitored, 49 percent of which failed. The majority of failures occurred in thinned stands. The goal of the current study was to continue the nest monitoring efforts initiated in 2001 to further determine post-treatment response by the avian community.

\section{MATERIALS AND METHODOLOGY}

Twelve study sites were established in the Clemson Experimental Forest during spring 2000 to serve as treatment plots in a randomized block design (see [15] for a map of the study area). Sites were selected based on stand age, size, and tree composition. Study sites ranged in age from 15 to 60 years and were blocked by tree size to reduce variability. Each of three blocks contained four treatment plots. Block 1 
was composed primarily of pulpwood-sized trees with a diameter at breast height $(\mathrm{dbh})$ of $15-25 \mathrm{~cm}$. Block 3 was composed of sawtimber-sized trees $(\mathrm{dbh}>25 \mathrm{~cm})$ and Block 2 consisted of a mixture of pulpwood and sawtimber-sized trees. Each site was a minimum of 14 hectares to accommodate the 10 hectare study plot and a buffer area of about 20 meters. ArcView GIS software was used to place 40 grid points that fit the shape of each plot. The first grid point was randomly selected. The remaining grid points were spaced 50 meters apart and numbered from the northeast corner and went from east to west in a zig-zag pattern.

Study sites were composed primarily of planted loblolly pine but a component of shortleaf pine (Pinus echinata Miller), Virginia pine (Pinus virginiana Miller), and various hardwood species were also present. The time since last thinning was at least 10 years and the time since last prescribed or wild fire was at least 5 years. Litter and woody debris occurred at high enough levels in each site to fuel a potentially catastrophic wildfire.

Treatments were planned and described by the USDA Forest Service. One of four treatments, as defined by FFS protocols, was assigned to each study site within a block. Treatments included thinning (Thin), prescribed burning (Burn), thinning followed by prescribed burning (Thin/Burn), and an untreated control (Control). During the 2000 growing season, southern pine beetles killed most of the trees in the thin-only treatment of block one. In winter 2000, this study site was replaced. Data collection for vegetation, fuels, and fire behavior followed the methods presented in the Southeastern Piedmont Study Plan [16].

Nest searching and monitoring took place within each plot during the breeding seasons of 2003 and 2004. Searches were alternated between plots throughout the nest searching season and followed the methodology of Zebehazy [15]. Systematic searches were conducted by walking the permanent gridpoints and looking and listening for behavioral cues of parental activity. Active nests were monitored every 2 to 3 days to observe the nest building stage, number of eggs or young, and nest fate. Number of eggs was determined on active nests by visual inspection with a retractable hand mirror or mirror attached to a $2 \mathrm{~m}$ galvanized metal pole. Contents of nests higher than $4 \mathrm{~m}$ and cavity nests were not determined due to height limitations. Cavity nest activity was determined by visual inspection. Cavities were considered active if adults were visiting or using the cavity [17]. Nest site disturbance was reduced by minimizing the time spent at each nest and placing nest markers at least $6 \mathrm{~m}$ from the nest. Nest success (\%) was approximated for each treatment by calculating the percent of fledged or failed nests for each guild and species. Nest discovery data were summarized and assigned to six categories (Table 1). Significance tests for treatment and block effects were not possible due to the small sample size of nests for each plot. Nevertheless, the data are valuable in that they can be used in future meta-analyses of treatment effects across multiple sites, so they are presented in a manner that allows use of the data for those reasons.
Table 1. Nest discovery and Guild Categories in the Piedmont Site of the National Fire and Fire Surrogate Study, Anderson, Oconee, and Pikens Counties, South Carolina 2003-2004

\begin{tabular}{|c|c|}
\hline & Species or Guild \\
\hline \multirow{5}{*}{ Picidae } & $\begin{array}{l}\text { Downy Woodpecker (Picoides pubescens } \\
\text { Linnaeus) }\end{array}$ \\
\hline & Hairy Woodpecker (Picoides villosus Linnaeus) \\
\hline & Northern Flicker (Colaptes auratus Linnaeus) \\
\hline & $\begin{array}{l}\text { Red-bellied Woodpecker (Melanerpes carolinus } \\
\text { Boddaert) }\end{array}$ \\
\hline & $\begin{array}{l}\text { Red-headed Woodpecker (Melanerpes } \\
\text { erythrocephalus Linneaus) }\end{array}$ \\
\hline \multirow{3}{*}{ Bark Gleaner } & Brown-headed Nuthatch (Sitta pusilla Latham) \\
\hline & $\begin{array}{l}\text { Carolina Chickadee (Poecile carolinensis } \\
\text { Audubon) }\end{array}$ \\
\hline & $\begin{array}{l}\text { Eastern Tufted Titmouse (Baeolophus bicolor } \\
\text { Linnaeus) }\end{array}$ \\
\hline \multirow{3}{*}{ Cavity Nester } & Picidae \\
\hline & Bark Gleaner \\
\hline & Eastern Bluebird (Sialia sialis Linnaeus) \\
\hline \multirow[t]{2}{*}{ Ground Nester } & $\begin{array}{l}\text { Chuck-will's-widow (Caprimulgis carolinensis } \\
\text { Gmelin) }\end{array}$ \\
\hline & Wild Turkey (Meleagris gallapavo Vieillot) \\
\hline \multirow{7}{*}{ Migrant } & $\begin{array}{l}\text { Blue-gray Gnatcatcher (Polioptila caerulea } \\
\text { Linnaeus) }\end{array}$ \\
\hline & Indigo Bunting (Passerina cyanea Linnaeus) \\
\hline & Prairie Warbler (Dendroica discolor Vieillot) \\
\hline & Red-eyed Vireo (Vireo olivaceus Linnaeus) \\
\hline & Summer Tanager (Piranga rubra Linnaeus) \\
\hline & Yellow-breasted Chat (Icteria virens Linnaeus) \\
\hline & $\begin{array}{l}\text { Yellow-billed Cuckoo (Coccyzus americanus } \\
\text { Linnaeus) }\end{array}$ \\
\hline \multirow{3}{*}{ Early Successional } & Indigo Bunting (Passerina cyanea Linnaeus) \\
\hline & Prairie Warbler (Dendroica discolor Vieillot) \\
\hline & Yellow-breasted Chat (Icteria virens Linnaeus) \\
\hline
\end{tabular}

\section{RESULTS}

Eighty-two nests were discovered and monitored during the 2003 and 2004 breeding season. Out of those nests, $72 \%$ were successful in fledging young and $28 \%$ failed due to predation, weather, or unknown causes. Total number of nests we discovered was higher in Thin/Burn and Burn plots than in Thin and Control plots. Number of nests of early successional species was higher in Thin/Burn plots than in Burn, Thin and Control plots. The number of nests of migratory species was higher in Burn and Thin/Burn plots than in Thin and Control plots (Table 2). 
Table 2. Number of Nests Found, and Numbers that Fledged or Failed, According to Treatment in the Piedmont site of the National Fire and Fire Surrogate Study, Anderson, Oconee, and Pickens Counties, South Carolina, 2003-2004.

\begin{tabular}{|c|c|c|c|c|c|c|c|c|}
\hline Guild & Species & Burn & Control & Thin & Thin/Burn & Fledge & Fail & Total \\
\hline \multirow{3}{*}{ Canopy Nesters } & Blue-gray Gnatcatcher & 2 & 1 & & 2 & 4 & 1 & 5 \\
\hline & Blue Jay & 1 & & & & & 1 & 1 \\
\hline & Red-eyed Vireo & 1 & & & & 1 & & 1 \\
\hline \multirow{6}{*}{ Cavity Nesters } & Brown-headed Nuthatch & 1 & & & 1 & 2 & & 2 \\
\hline & Carolina Chickadee & & & & 1 & 1 & & 1 \\
\hline & Downy Woodpecker & 3 & 2 & & & 5 & & 5 \\
\hline & Eastern Bluebird & 2 & & & & 2 & & 2 \\
\hline & Red-bellied Woodpecker & 1 & & 2 & 3 & 6 & & 6 \\
\hline & Red-headed Woodpecker & 1 & & & & 1 & & 1 \\
\hline \multirow{3}{*}{ Ground Nesters } & Chuck-will's-widow & 1 & 1 & 1 & 1 & 2 & 2 & 4 \\
\hline & Eastern Towhee & & & & 1 & & 1 & 1 \\
\hline & Wild Turkey & 5 & 2 & 2 & 3 & 7 & 5 & 12 \\
\hline \multirow{3}{*}{ Shrub Nesters } & Indigo Bunting & 1 & & & 6 & 7 & & 7 \\
\hline & Mourning Dove & 2 & & & 3 & 1 & 4 & 5 \\
\hline & Northern Cardinal & 2 & 2 & 2 & 2 & 3 & 5 & 8 \\
\hline
\end{tabular}

All indigo bunting (Passerina cyanea Linnaeus), yellow breasted chat (Icteria virens Linnaeus), and prairie warbler (Dendroica discolor Vieillot) nests were found in tree or shrub sprouts less than $5 \mathrm{~m}$ tall. Four of the seven indigo bunting nests occurred in sprouts of white oak (Quercus alba Linnaeus), scarlet oak (Quercus coccinea Meunchhausen), and water oak (Quercus nigra Linnaeus). The remaining nests were found in bitternut hickory (Carya cordiformis Wangenheim), persimmon (Disopyros virginiana Linnaeus), and sweetgum (Liquidambar styraciflua Linnaeus). The four yellow-breasted chat nests were found in Chinese privet (Ligustrum sinense Loureiro), persimmon, sparkleberry (Vaccinium arboreum Marshall), and water oak. The single prairie warbler nest was found in a winged elm (Ulmus alata Michaux). The eastern towhee (Pipilo erythrophthalmus Linnaeus) nest was found in dense patch of mixed grass species beneath a clump of downy danthonia (Danthonia sericea Nuttall). Although the eastern towhee nest failed, each indigo bunting, yellow-breasted chat, and prairie warbler nest attempt was successful.

\section{DISCUSSION AND CONCLUSION}

We found more nests in plots with prescribed burning and a combination of prescribed burning and thinning. The relationship between true nest density and density of nests we found remains unclear, but the low population densities of birds and the generally open aspect of the habitats suggests that we found most nests in the study plots. Nest density in Thinned plots was more similar to Control plots than in Burn and Thin/Burn plots. Functional groups most influenced by Burn and Thin/Burn treatments during the breeding season were migrants, early successional species, birds with high conservation priority, and ground nesters. The increase in herbaceous cover and diversity and eventual increase in stump sprouts resulted from the reduction in pine/hardwood midstory cover and basal area during treatment. Higher quantities of herbaceous material, shrubs, and small diameter trees were important for avian functional groups because it provided more cover, foraging opportunity, and nesting substrate in Burn and Thin/Burn plots. Burning can shift the guild structure of stands by increasing the number of early successional species and their abundance [18]. 
Zebehazy [15] reported few differences in avian abundance between treatment and control plots on the southeastern Piedmont FFS site from 2001-2002. The abundance of foliage-gleaning and canopy-nesting species was higher in Thin plots than in the Control plots. There were no results for the Thin/Burn treatment because the treatment was not implemented until March 2002. The difference in number of nests we found across treatments in this study result in part from the increased herbaceous, shrub, and stump sprout growth that took place over time between the two studies. The response of woody vegetation to fire, and time since fire, influenced the abundance of shrub-nesting species. Wilson et al. [19] found that indigo bunting abundance was highest 3 years after fire and that prairie warbler abundance increased each year post-fire during the study. Shrub cover increases after fire because many tree and shrub species produce stump sprouts soon after being top-killed by fire. In 2001, five northern cardinal nests were found and represented the only shrub nesting species found nesting for that year. In 2002, four indigo bunting and 12 northern cardinal nests were found [15]. Yellow-breasted chat, prairie warbler, and eastern towhee nests were not found until 2003 and 2004. The discovery of yellow-breasted chat and prairie warbler nests in 2003 and 2004 was concomitant with the increase in shrub and stump sprout cover since treatment. However, it is likely that eastern towhees nested in treatment areas before 2003, but the nests of this species are very cryptic and difficult to find.

Nest densities of indigo buntings, yellow breasted chats, prairie warblers, and other shrub/ground nesting species in Burn and Thin/Burn treatments were likely higher than the number of nests we found. Searching each study site was slow and difficult due to the dense post-fire scrub of hardwood sprouts, blackberry (Rubus spp. Linnaeus) thickets, and large (10 ha) treatment areas. Completed nests that went undetected during the breeding season were sometimes found during late summer and fall 2003 and 2004 while collecting nest vegetation data.

Thin/Burn plots provided the best nest areas for the cavity-nesting Carolina chickadee, eastern tufted titmouse, and brown-headed nuthatch. The eastern tufted titmouse (Baeolophus bicolor) is also a gleaner and secondary cavity nester but there was no pattern to the distribution of this species across study sites. Except for one observation in Block 1 Control, the brown-headed nuthatch was detected in Block 1 Thin/Burn, Block 2 Thin/Burn, and Block 3 Burn and nested exclusively in large pine snags within Block 2 Thin/Burn and Block 3 Burn. The habitat in these two study sites is similar to that described by other authors that found significantly higher numbers of this species in burned and thinned stands. Numerous snags created from hot spots during the burn and from southern pine beetle damage were ideal nesting substrate for these secondary cavity nesters. Cavity trees were often located among pine and hardwood snags of various sizes and patches of mid-story hardwoods that provided an assortment of foraging opportunities for these species.

Northern cardinal nests were concentrated in Block 1 and Block 2. The high density of small diameter trees in Block 1, compared to Block 2 and Block 3, partially explains the higher number of northern cardinal nests in Block 1 .
Northern cardinals inhabit midstory vegetation and thickets [20,21]. This habitat type was prevalent in Block 1, especially in Block 1 Burn, Thin, and Control. Blue-headed vireos are mid-canopy species and nests of this species were found in mid-canopy and canopy locations. Over half of the woodpecker cavity nests were found in Block 3 where most cavity trees were medium to large $(25-45 \mathrm{~cm})$ loblolly pine snags.

Eight of the 12 wild turkey (Mellagris gallopavo) nests were found in Block 2. Wild turkey hens establish nests early in the spring and nest sites are usually concealed with debris from the previous growing season. Wild turkey nests were usually found among debris piles created from southern pine beetle damage. The debris was usually covered with muscadine (Vitis rotundifolia Michaux) tangles or surrounded by bunch grasses and stump sprouts. This habitat type was present in most study sites but especially common in Block 2 Burn, Block 2 Control, and Block 2 Thin/Burn.

Species that appeared to be more abundant in Burn and Thin/Burn plots were ground and shrub nesters that inhabit pine-shrub-grassland habitats. Many species that require early successional habitat are in decline at the regional and national level [22]. Seven of the 22 species (brown-headed nuthatch, eastern towhee, northern flicker, pine warbler, prairie warbler, red-headed woodpecker, and yellow-billed cuckoo) are listed in Partner's in Flight (PIF) species prioritization tiers. PIF is an organization of public and private agencies and organizations that work to conserve birds in the western hemisphere. PIF focuses on Neotropical migrants, landbirds, and marine or aquatic species that require terrestrial habitat. PIF developed a system to prioritize bird species within physiographic regions based on seven parameters. The parameters are based on local and global information and reflect the need for different levels of conservation $[23,24]$. PIF scoring data are available for the Southern Piedmont and species with a PIF score of 19 have "moderate priority". Conservation priority increases from 19 to a status of "high priority" when PIF $\geq 23$ [25].

Brown-headed nuthatches, eastern towhees, northern flickers, prairie warblers, and yellow-billed cuckoos are exhibiting declines in South Carolina [26]. Brown-headed nuthatches and prairie warblers have PIF composite scores of 25 and 24, respectively. Both are listed as species with high overall priority and there is concern for the conservation of these species throughout their range. Eastern towhees, northern flickers, and yellow-billed cuckoos are species with high regional concern and are currently in decline in the core of their range. These species are in need of short-term conservation action to reverse or stabilize trends. Redheaded woodpeckers have high priority, are included on the U.S. watch list, and warrant conservation attention wherever they occur [25].

Prescribed burning and thinning for fuel reduction appeared to affect avian nest density. Burn and Thin/Burn plots supported nesting species with high PIF scores. Nest density had a positive response to the habitat conditions created by prescribed fire and thinning. FFS studies in the Southern Appalachians, Gulf Coastal Plain, Atlantic Coastal Plain, and in western ponderosa pine have reported similar findings. The abundant herbaceous cover and woody sprouts resulting from thinning and prescribed burning seem to be 
most attractive to early successional species, ground foragers, and bark gleaners. During the breeding season thinned and burned plots provided a diversity of nest substrates for migrant and resident bird species. Number of nests we found of shrub/scrub and ground nesting birds were much higher in burned and thinned stands than in stands not receiving fuel reduction treatment.

Our study suggests that pine plantations in the southern Piedmont with high basal areas and closed canopy conditions do not attract as many species in the avian community unless the plantations are thinned and burned. An applied approach implementing prescribed fire and midstory thinning in upland Piedmont forests would be beneficial for Piedmont bird conservation. In the Upper Piedmont, upland forest regeneration without disturbance can result in late seral stages of closed canopy forest. Closed canopy conditions would not provide the dense herbaceous understory and shrub component needed to support breeding species in need of conservation in the Southern Piedmont.

\section{ACKNOWLEDGEMENTS}

This is Contribution Number 213 of the National Fire and Fire Surrogate Project (FFS), funded by the U.S. Joint Fire Science Program and by the US Forest Service, Southern Research Station (SRS-4156) through the National Fire Plan. Thanks also go to W. Bridges for statistical assistance and R. Phillips for environmental data. We are grateful to $\mathrm{C}$. McGhee, B. Cromer, L. Lowry, and S. McCullers for assistance with fieldwork.

\section{APPENDIX 1}

Sample sizes of nests of most species were too small to allow statistical evaluations of treatment effects. To facilitate future meta-analyses, we report sample sizes of nests (n), number of nests failing to fledge young, and total exposure days of nests in the plots of the Piedmont site of the National Fire and Fire Surrogate Study, Anderson, Oconee, and Pickens Counties, South Carolina, 2003-2004. Abbreviations for treatments are Control (C), Burn (B), Thin (T), and Thin and Burn (TB). Bird species are listed in alphabetical order by common name.

\begin{tabular}{|c|c|c|c|c|c|}
\hline Species & Year & Treatment & $\mathbf{N}$ & Failures & Exposure (d) \\
\hline \hline \multirow{4}{*}{$\begin{array}{c}\text { Blue-gray } \\
\text { Gnatcatcher }\end{array}$} & 2003 & $\mathrm{~B}$ & 1 & 1 & 14 \\
\cline { 2 - 6 } & 2004 & $\mathrm{~B}$ & 1 & 0 & 6 \\
\cline { 2 - 6 } & 2004 & $\mathrm{C}$ & 1 & 0 & 35 \\
\cline { 2 - 6 } & 2004 & $\mathrm{~TB}$ & 2 & 0 & 5 \\
\hline Blue Jay & 2003 & $\mathrm{~B}$ & 1 & 1 & 15 \\
\hline $\begin{array}{c}\text { Brown-headed } \\
\text { |Nuthatch }\end{array}$ & 2004 & $\mathrm{~B}$ & 1 & 0 & 3 \\
\cline { 2 - 6 } & 2004 & $\mathrm{~TB}$ & 1 & 0 & 19 \\
\hline $\begin{array}{c}\text { Carolina } \\
\text { Chickadee }\end{array}$ & 2004 & $\mathrm{~TB}$ & 1 & 0 & 18 \\
\hline \multirow{3}{*}{$\begin{array}{c}\text { Chuck-will's- } \\
\text { widow }\end{array}$} & 2003 & $\mathrm{~B}$ & 1 & 1 & 7 \\
\cline { 2 - 6 } & 2004 & $\mathrm{~T}$ & 1 & 0 & 2 \\
\cline { 2 - 6 } & 2004 & $\mathrm{~TB}$ & 1 & 0 & 26 \\
\hline
\end{tabular}

\begin{tabular}{|c|c|c|c|c|c|}
\hline Species & Year & Treatment & $\mathbf{N}$ & Failures & Exposure (d) \\
\hline \multirow{3}{*}{$\begin{array}{c}\text { Downy } \\
\text { Woodpecker }\end{array}$} & 2003 & B & 2 & 0 & 15 \\
\hline & 2003 & $\mathrm{C}$ & 2 & 0 & 12 \\
\hline & 2004 & B & 1 & 0 & 6 \\
\hline \multirow{2}{*}{$\begin{array}{l}\text { Eastern } \\
\text { Bluebird }\end{array}$} & 2003 & B & 1 & 0 & 7 \\
\hline & 2004 & B & 1 & 0 & 6 \\
\hline Eastern Towhee & 2004 & TB & 1 & 1 & 12 \\
\hline \multirow{2}{*}{$\begin{array}{l}\text { Eastern Tufted } \\
\text { Titmouse }\end{array}$} & 2004 & $\mathrm{C}$ & 1 & 0 & 18 \\
\hline & 2004 & TB & 2 & 0 & 18 \\
\hline \multirow{2}{*}{$\begin{array}{c}\text { Hairy } \\
\text { Woodpecker }\end{array}$} & 2004 & B & 1 & 0 & 8 \\
\hline & 2004 & TB & 1 & 0 & 7 \\
\hline \multirow{3}{*}{$\begin{array}{l}\text { Indigo } \\
\text { Bunting }\end{array}$} & 2003 & TB & 2 & 0 & 30 \\
\hline & 2004 & B & 1 & 0 & 3 \\
\hline & 2004 & TB & 4 & 0 & 27 \\
\hline \multirow{4}{*}{$\begin{array}{l}\text { Mourning } \\
\text { Dove }\end{array}$} & 2003 & B & 1 & 1 & 3 \\
\hline & 2003 & $\mathrm{~TB}$ & 1 & 1 & 3 \\
\hline & 2004 & B & 1 & 0 & 16 \\
\hline & 2004 & TB & 2 & 2 & 23 \\
\hline \multirow{5}{*}{$\begin{array}{l}\text { Northern } \\
\text { Cardinal }\end{array}$} & 2003 & TB & 1 & 0 & 12 \\
\hline & 2004 & B & 2 & 2 & 22 \\
\hline & 2004 & $\mathrm{C}$ & 2 & 2 & 31 \\
\hline & 2004 & $\mathrm{~T}$ & 2 & 1 & 18 \\
\hline & 2004 & $\mathrm{~TB}$ & 1 & 0 & 3 \\
\hline $\begin{array}{l}\text { Northern } \\
\text { Flicker }\end{array}$ & 2004 & $\mathrm{~TB}$ & 1 & 0 & 14 \\
\hline $\begin{array}{l}\text { Prairie } \\
\text { Warbler }\end{array}$ & 2004 & TB & 1 & 0 & 5 \\
\hline \multirow{5}{*}{$\begin{array}{l}\text { Red-bellied } \\
\text { Woodpecker }\end{array}$} & 2003 & B & 1 & 0 & 3 \\
\hline & 2003 & $\mathrm{~T}$ & 1 & 0 & 6 \\
\hline & 2003 & TB & 1 & 0 & 14 \\
\hline & 2004 & $\mathrm{~T}$ & 1 & 0 & 35 \\
\hline & 2004 & $\mathrm{~TB}$ & 2 & 0 & 76 \\
\hline $\begin{array}{l}\text { Red-eyed } \\
\text { Vireo }\end{array}$ & 2004 & B & 1 & 0 & 29 \\
\hline $\begin{array}{l}\text { Red-headed } \\
\text { Woodpecker }\end{array}$ & 2004 & B & 1 & 0 & 47 \\
\hline \multirow{4}{*}{$\begin{array}{l}\text { Solitary } \\
\text { Vireo }\end{array}$} & 2003 & B & 1 & 0 & 21 \\
\hline & 2003 & $\mathrm{~TB}$ & 1 & 1 & 9 \\
\hline & 2004 & B & 1 & 1 & 10 \\
\hline & 2004 & $\mathrm{~TB}$ & 2 & 1 & 8 \\
\hline \multirow{3}{*}{$\begin{array}{l}\text { Summer } \\
\text { Tanager }\end{array}$} & 2004 & B & 2 & 0 & 16 \\
\hline & 2004 & $\mathrm{~T}$ & 1 & 1 & 10 \\
\hline & 2004 & $\mathrm{~TB}$ & 1 & 0 & 25 \\
\hline \multirow{2}{*}{$\begin{array}{l}\text { Wild } \\
\text { Turkey }\end{array}$} & 2003 & B & 3 & 0 & 13 \\
\hline & 2003 & C & 1 & 1 & 17 \\
\hline
\end{tabular}




\begin{tabular}{|c|c|c|c|c|c|}
\hline Species & Year & Treatment & $\mathbf{N}$ & Failures & Exposure (d) \\
\hline \hline \multirow{4}{*}{$\begin{array}{c}\text { Wild } \\
\text { Turkey }\end{array}$} & 2003 & T & 2 & 1 & 20 \\
\cline { 2 - 6 } & 2003 & TB & 1 & 0 & 10 \\
\cline { 2 - 6 } & 2004 & B & 2 & 1 & 21 \\
\cline { 2 - 6 } & 2004 & C & 1 & 1 & 7 \\
\cline { 2 - 6 } & 2004 & TB & 2 & 1 & 11 \\
\hline \multirow{2}{*}{$\begin{array}{c}\text { Yellow-billed } \\
\text { Cuckoo }\end{array}$} & 2004 & T & 1 & 0 & 19 \\
\hline \multirow{3}{*}{$\begin{array}{c}\text { Yellow-breasted } \\
\text { Chat }\end{array}$} & 2003 & TB & 1 & 0 & 11 \\
\cline { 2 - 6 } & 2004 & B & 2 & 0 & 21 \\
\cline { 2 - 6 } & 2004 & TB & 1 & 0 & 14 \\
\hline
\end{tabular}

[10] Terborgh J. Where have all the birds gone? Princeton (NJ): Princeton University Press 1989.

[11] Martin TE. Nest predation among vegetation layers and habitat types: revising the dogmas. American Naturalist 1993; 141: 897913.

[12] Barber DR, Martin TE, Melchiors MA, Thill RE, Wigley TB. Nesting success of birds in different silvicultural treatments in southeastern U.S. pine forests. Conserv Biol 2001; 15(1): 196-207.

[13] Aquilani SM, LeBlanc DC, Morrell TE. Effects of prescribed surface fires on ground- and shrub-nesting neotropical migratory birds in a mature Indiana oak forest, USA. Nat Area J. 2000; 20(4): 317-24.

[14] Duguay JP, Wood PB, Miller GW. Effects of timber harvests on invertebrate biomass and avian nest success. Wildl Soc Bull 2000; 28(1): 1123-31.

[15] Zebehazy LA. Avian and arthropod community responses to fuel reduction treatments in the Upper Piedmont of South Carolina. MS [thesis]. Clemson (SC): Clemson University; 2002.

[16] Waldrop TA. Study Plan: A national study of the consequences of fire and fire surrogate treatments-South Carolina Piedmont. Clemson, SC; 2000. USDA Forest Service, SRS-4104(2).

[17] Martin TE. Breeding productivity considerations: What are the appropriate habitat features for management? In: Hagan J, Johnston DW, editors. Ecology and conservation of neotropical migrants. Washington DC: Smithsonian Institution Press 1992; pp. 455-73.

[18] Dickson JG. Effects of forest burning on songbirds. In: Wood GW, Ed. Prescribed fire and wildlife in southern forests. South Carolina: Belle W. Baruch Forest Science Institute, Clemson University 1981; pp. 67-72.

[19] Wilson CW, Masters RE, Bukenhofer GA. Breeding bird response to pine-grassland community restoration for red-cockaded woodpeckers. J Wildlife Manage 1995; 59: 56-67.

[20] Dickson JG, Segelquist CA. Breeding bird populations in pine and pine-hardwood forest in Texas. J Wildlife Manage 1979; 43: 54955.

[21] Dickson JG, Noble RE. Vertical distribution of birds in a Louisiana bottom-land forest. Wilson Bull 1978; 90: 19-30.

[22] Church KE, Sauer JR, Droege S. Population trends of quails in North America. In: Church KE, Daily TV, Eds. Quail III: national quail symposium. Pratt (KA), Kansas Department of Wildlife and Parks 1993; pp. 44-54.

[23] Beissinger SR, Reed JR, Wunderle JM Jr., Robinson SK, Finch DM. Report of the AOU conservation committee on the partner's in flight species prioritization plan. Auk 2000; 117: 549-61.

[24] Carter MF, Hunter WC, Paisley DN, and Rosenberg KV. Setting conservation priorities for landbirds in the United States: The partners in flight approach. Auk 2000; 117(2): 541-48.

[25] Panjabi A. The partners in flight handbook on species assessment and prioritization. Brighton (CO). Rocky Mountain Bird Observatory. 2001

[26] Sauer JR, Hines JE, Fallon J. The North American breeding bird survey. Results and analysis 1966-2004. Version 2005.2. USGS Patuxent Wildlife Research Center, Laurel (MD) 2005.

(C) Kilpatrick et al.; Licensee Bentham Open.

This is an open access article licensed under the terms of the Creative Commons Attribution Non-Commercial License (http://creativecommons.org/licenses/by$\mathrm{nc} / 3.0 /$ ) which permits unrestricted, non-commercial use, distribution and reproduction in any medium, provided the work is properly cited. 